\title{
Effectiveness of aqueous and hydroalcoholic extracts of Acanthospermum australe (Loefl.) Kuntze against diarrhea-inducing bacteria
}

\author{
R. Mallmann ${ }^{a}$, E. M. Ethur ${ }^{b *}$, P. Bianchetti ${ }^{a}$, D. Faleiro ${ }^{a}$, L. Hoehne ${ }^{b}$, M. I. Goettert ${ }^{a}$ \\ aUniversidade do Vale do Taquari - UNIVATES, Centro de Ciências Biológicas e da Saúde, \\ Avelino Tallini, $\mathrm{n}^{\circ}$ 171, Bairro Universitário, CEP 95900-000, Lajeado, RS, Brazil \\ bUniversidade do Vale do Taquari - UNIVATES, Centro de Ciências Exatas e Tecnológicas, \\ Avelino Tallini, $\mathrm{n}^{\circ}$ 171, Bairro Universitário, CEP 95900-000, Lajeado, RS, Brazil \\ *e-mail: eduardome@univates.br
}

Received: August 1, 2016 - Accepted: May 17, 2017 - Distributed: November 30, 2018

(With 1 figure)

\begin{abstract}
Leaves and roots of Acanthospermum australe (Asteraceae) have been used in Brazilian folk medicine for the treatment of various ailments including diarrhea, skin diseases, blennorrhagia, dyspepsia, parasitic worms and malaria. The aim of study was to characterize the chemical profiles of the aqueous and hydroalcoholic extracts of leaves and roots of A. australe, and to evaluate their antimicrobial activities against diarrhea-inducing bacteria (Enterococcus faecalis, Shigella dysenteriae and Yersinia enterocolitica), as well as their cytotoxic properties. Aqueous leaf extracts were obtained by infusion, while aqueous root extracts were obtained by decoction. The hydroalcoholic leaf and root extracts were prepared by maceration in $90 \%$ ethanol for 3 days. Antimicrobial activity was assessed using standard techniques and cytotoxicity was evaluated using Chinese hamster ovary cells CHO-K1. Chemical analysis revealed the presence of tannins, flavonoids, saponins and phenolic compounds in the extracts. Although root extracts were not effective against $E$. faecalis, leaf extracts at concentrations of $20 \mathrm{mg} / \mathrm{mL}$ exhibited bactericidal activities against this microorganism. The hydroalcoholic root extract was unique in presenting a bactericidal effect against $S$. dysenteriae. None of the extracts showed bacteriostatic or bactericidal activities against $Y$. enterocolitica. The results presented herein demonstrate that the Gram-positive E. faecalis and the Gram-negative $S$. dysenteriae were susceptible to A. australe extracts, although bacteriostatic/bactericidal activities were only observed at concentrations considered too high for clinical application. Our results support the ethnopharmacological use of $A$. australe in the treatment of gastrointestinal disorders, particularly diarrhea caused by infectious bacteria, although further studies are required to determine the anti-diarrhea effects and the toxicities of the extracts in vivo.
\end{abstract}

Keywords: Acanthospermum australe, diarrhea, antimicrobial activity, cytotoxicity, flavonoids, polyphenols.

\section{Eficácia de extratos aquosos e hidroalcoólicos de Acanthospermum australe (Loefl.) Kuntze contra bactérias indutoras de diarreia}

\section{Resumo}

Folhas e raízes de Acanthospermum australe (Asteraceae) têm sido usadas na medicina popular brasileira para o tratamento de várias doenças, incluindo diarreia, doenças de pele, blenorragia, dispepsia, vermes parasitas e malária. O objetivo deste estudo foi caracterizar os perfis químicos dos extratos aquosos e hidroalcoólicos das raízes e folhas de A. australe, e avaliar as suas atividades antimicrobianas contra as bactérias indutoras de diarreia (Enterococcus faecalis, Shigella dysenteriae e Yersinia enterocolitica), bem como sua citotoxicidade. Os extratos aquosos de folhas foram obtidos por infusão, enquanto que os extratos aquosos de raízes foram obtidos por decocção. Os extratos hidroalcoólicos de folhas e raízes foram preparados por maceração em etanol a 90\% durante 3 dias. A atividade antimicrobiana foi avaliada utilizando técnicas padrão e a citotoxicidade foi avaliada utilizando células de ovário de hamster chinês CHO-K1. A análise química revelou a presença de taninos, flavonóides, saponinas e compostos fenólicos nos extratos. Apesar de extratos de raiz não foram eficazes contra E. faecalis, extratos de folhas em concentrações de $20 \mathrm{mg} / \mathrm{mL}$ apresentaram atividades bactericidas contra este microrganismo. O extrato hidroalcoólico de raiz foi o único a apresentar um efeito bactericida contra $S$. dysenteriae. Nenhum dos extratos apresentaram atividades bacteriostáticas ou bactericidas contra $Y$. enterocolitica. Os resultados apresentados demonstram que a bactéria Gram-positiva E. faecalis e a Gram-negativa S. dysenteriae foram suscetíveis aos extratos de A. australe, embora as atividades bacteriostáticos/bactericidas tenham sido apenas observados em concentrações consideradas elevadas para aplicação clínica. Os nossos resultados apoiam a 
utilização de etnofarmacológica de $A$. australe no tratamento de perturbações gastrointestinais, especialmente diarreia causadas por bactérias infecciosas, embora sejam necessários mais estudos para determinar os efeitos anti-diarreia e as toxicidades dos extratos in vivo.

Palavras-chave: Acanthospermum australe, diarreia, atividade antimicrobiana, citotoxicidade, flavonoides, polifenóis.

\section{Introduction}

Detailed knowledge of plant-derived medicines has proven useful in drug discovery and forms the base of modern phytotherapy. Indeed, the plant kingdom has been a constant source of active principles for several diseases, from pain and fever to cancer, and continues to be an invaluable font of lead molecules for developing novel pharmaceutical drugs and agrochemicals (Harbone, 1998; Hofling et al., 2010; Veiga Júnior et al., 2005).

The genus Acanthospermum (Asteraceae) includes six accepted species, namely Acanthospermum australe (Loefl.) Kuntze, A. consobrinum S.F.Blake, A. glabratum (DC.) Wild, A. hispidum DC., A. humile DC. and $A$. microcarpum B.L.Rob. Of these, A. hispidum is widespread in tropical America and has been the most studied with respect to its medicinal properties, which are principally antibacterial and antifungal (Chakraborty et al., 2012). However, A. australe, which grows in open areas in Brazil and is considered an invasive weed in some crops and pastures (Lorenzi and Matos, 2002), is widely used in folk medicine for the treatment of diarrhea, skin diseases, blennorrhagia, dyspepsia, parasitic worms and malaria, among other ailments (Rodrigues and Carvalho, 2001; Lorenzi and Matos, 2002). Typically, the leaves and roots of this plant are employed in the form of teas or applied as external dressings.

Diarrhea may represent an occasional inconvenience but can be a fatal ailment, especially for young malnourished children or individuals with compromised immune systems. Diarrhea is normally caused by infection of the intestinal tract by bacteria (Campylobacter, Salmonella and Shigella), viruses (rotavirus, norovirus and adenovirus) or parasites (Giardia lamblia, Entamoeba histolytica and Cryptosporidium) that are present in contaminated food or drinking-water or enter the system as a result of poor hygiene (World Health Organization, 2013).

In view of the above, the present study aimed to characterize the chemical profiles of the aqueous and hydroalcoholic extracts from leaves and roots of $A$. australe, to evaluate their antimicrobial activities against the diarrhea-inducing bacteria Enterococcus faecalis, Shigella dysenteriae, and Yersinia enterocolitica, and to determine their antioxidant properties and cytotoxic activity.

\section{Materials and Methods}

\subsection{Plant material and preparation of extracts}

Leaves and roots of Acanthospermum australe (Loefl.) Kuntze (Flora Digital do Rio Grande do Sul, 2015), commonly known in Brazil as carrapicho-rasteiro, were collected during June 2014 from plants growing in Lajeado, state of
Rio Grande do Sul, Brazil (GPS coordinates: 29²6'52”S; $52^{\circ} 0$ '56”'W). The plant material was botanically identified by Dr. Elisete Maria de Freitas (Centro Universitário UNIVATES) and the voucher specimen was deposited at the Herbário do Vale do Taquari, Museu de Ciências Naturais UNIVATES under accession number HVAT2346.

Freshly harvested leaves and roots were separated, washed under running water and dried in a hot air oven at $40{ }^{\circ} \mathrm{C}$ for $22 \mathrm{~h}$. Aqueous root extracts were obtained by decoction while aqueous leaf extracts were obtained by infusion in accordance with the techniques employed in traditional folk medicine. Hydroalcoholic extracts of roots and leaves were prepared by maceration in $90 \%$ ethanol and exhaustive extraction over 3 days. In each case, the proportion of plant material to extractant was maintained at 1:10 (w/v). Following removal of spent plant material, extracts were concentrated at $40^{\circ} \mathrm{C}$ in a rotary evaporator under vacuum and the residues were stored in a freezer at $-3{ }^{\circ} \mathrm{C}$ until required for assay. Percentage yields were calculated from the expression $(\mathrm{w} 1 / \mathrm{w} 0) \times 100$ where $\mathrm{w} 1$ is the dry weight of the extract and w0 is the weight of the initial dried plant material.

\subsection{Determination of phytochemical profiles of extracts}

The presence of alkaloids, saponins, flavonoids, tannins, coumarins, quinones and phenolic compounds in aqueous and hydroalcoholic extracts of $A$. australe were assessed using the methods described by Harbone (1998) and Simões et al. (2004). A modified version of the method of Sousa et al. (2007) was employed in the determination of polyphenol content. Briefly, a $40 \mu \mathrm{L}$ aliquot of extract was transferred to a glass tube containing $3.16 \mathrm{~mL}$ of deionized water, $200 \mu \mathrm{L}$ of $1 \mathrm{~N}$ Folin Ciocalteau reagent and $600 \mu \mathrm{L}$ of $15 \%$ sodium carbonate solution. After shaking, the tubes were allowed to stand for $30 \mathrm{~min}$ in a water bath at $40{ }^{\circ} \mathrm{C}$ and absorbance was measured at $765 \mathrm{~nm}$ using a Genesys $10 \mathrm{~S}$ spectrophotometer (Thermo Fisher Scientific, Waltham, MA, USA). Calibration curves were constructed in a similar manner using $40 \mu \mathrm{L}$ aliquots of solutions containing standard gallic acid at concentrations of $50,100,150,250$ and $500 \mathrm{mg} / \mathrm{L}$. The polyphenol contents of the extracts were determined by reference to the calibration curves and expressed as mg of gallic acid equivalent (GAE)/g. All samples were analyzed in triplicate.

\subsection{Assay of antimicrobial activity}

Activities of $A$. australe extracts against Enterococcus faecalis (ATCC 51299), Shigella dysenteriae (ATCC 13313) and Yersinia enterocolitica (ATCC 9610) were evaluated according to the methodology recommended by the Clinical and Laboratory Standards Institute - CLCI (2012). Bacterial strains, which were provided by the 
Laboratório de Microrganismos de Referência da Fundação Oswaldo Cruz (FIOCRUZ), were suspended in brain heart infusion (BHI) liquid medium enriched with $1 \%$ glucose and cultivated in Petri dishes containing agar BHI for $24 \mathrm{~h}$ at $37{ }^{\circ} \mathrm{C}$ (for E. faecalis and S. dysenteriae) or at $28{ }^{\circ} \mathrm{C}$ (for $Y$. enterocolitica). Inocula for the minimum inhibitory concentration (MIC) and minimum bactericidal concentration (MBC) tests were prepared by suspending microorganisms separately in sterile $0.85 \%$ saline solution until the turbidity was equivalent to $0.5 \mathrm{McF}$ arland standard (equivalent to $1.5 \times 10^{8}$ colony forming units $/ \mathrm{mL}$ ). The tests were performed in microplates comprising 96-wells, each of which contained a standardized aliquot of the inoculum. Stock solutions containing plant extracts at concentrations of $40 \mathrm{mg} / \mathrm{mL}$ were subjected to $1: 1$ serial dilutions and the diluted extracts (in the range 20 to $5 \mathrm{mg} / \mathrm{L}$ ) were transferred separately to adjacent wells. Plates were subsequently incubated for $24 \mathrm{~h}$ at $37^{\circ} \mathrm{C}$ (for E. faecalis and $S$. dysenteriae) or at $28^{\circ} \mathrm{C}$ (for Y. enterocolitica), and turbidity within the well was considered an indication of bacterial growth. Appropriate controls were performed using BHI medium and $0.4 \%$ chloramphenicol solution in the presence or absence of inoculum, and all assays were carried out in triplicate.

The presence of microbial growth was verified by the addition of a $30 \mu \mathrm{L}$ aliquot of the redox indicator triphenyl tetrazolium chloride (TTC; $0.5 \%$ solution) or of the blue dye resazurin $(0.02 \%$ solution $)$ whereby, in the presence of viable living cells, the former is reduced to red 1,3,5-triphenylformazan and the latter to pink fluorescent resorufin. The contents of wells that produced negative reactions to these tests were plated on BHI medium and incubated under the conditions described above in order to determine whether the extracts were bacteriostatic, bactericidal or ineffective against the microorganism. For extracts that exhibited bactericidal activities, MBC values were determined by inoculating aliquots of the assay mixtures from wells that showed no microbial growth onto the surface of sterile BHI agar medium. The plates were incubated for $24 \mathrm{~h}$ in an oven maintained at $36^{\circ} \mathrm{C}+/-1{ }^{\circ} \mathrm{C}$ and subjected to visual inspection. Signs of growth of the microorganism on the medium indicated that the extracts possessed bacteriostatic activity, while the absence of growth implied that the oil sample was bactericidal. For $Y$. enterocolitica the plates were incubated for $24 \mathrm{~h}$ in an oven maintained at $28{ }^{\circ} \mathrm{C}+/-1{ }^{\circ} \mathrm{C}$.

\subsection{Assay of cytotoxicity}

Epithelial cells from CHO-K1 chinese hamster ovary were acquired from Rio de Janeiro - Cell Bank. CHO-K1 cells were culturedin Dulbecco's Modified Eagle's medium (DMEM) (Sigma-Aldrich) + Nutrient Mixture F-10 Ham medium (Ham's F-10) (Sigma-Aldrich), both supplemented $10 \%$ fetal bovine serum (FBS) (Cultilab), penicillin $(60 \mu \mathrm{g} / \mathrm{mL})$ (Sigma-Aldrich) and streptomycin $(100 \mu \mathrm{g} / \mathrm{mL})$ (Sigma-Aldrich). Cells were incubated at $37{ }^{\circ} \mathrm{C}$ in a humidified atmosphere containing $5 \% \mathrm{CO}_{2}$
(Freshney, 2010). Cell viability was assessed using the Trypan blue (Sigma-Aldrich) exclusion method.

Toxicity assays were performed in 96-well microplates using a modification of the method of Silva Júnior et al. (2014). Cells were seeded at a density of $2 \times 10^{4}$ cells per well in medium supplemented with $10 \%$ FBS and the plates were incubated for adhesion at $37^{\circ} \mathrm{C}$ in a humidified atmosphere containing $5 \% \mathrm{CO}_{2}$ for 4 to $5 \mathrm{~h}$. Subsequently, cells were washed with saline solution, treated with doxorubicin $(58,5.8,0.58$ e $0.058 \mu \mathrm{g} / \mathrm{mL})$ (Sigma-Aldrich), used as a standard, and with aqueous solutions of the plant extracts $(100 \mu \mathrm{g} / \mathrm{mL})$, containing dimethyl sulfoxide at a final concentration of no more than $1 \%$, and incubated for $48 \mathrm{~h}$ under the conditions stated above. After this time, the treatments were removed and added medium with $10 \%$ solution of Alamar Blue (Invitrogen). After $5 \mathrm{~h}$ of incubation, absorbance was measured at $540 \mathrm{~nm}$ (oxidized state) and $630 \mathrm{~nm}$ (reduced state) using a SpectraMax i3 (Molecular Devices).

All experiments were done, at least, in triplicate. The results were expressed by the cell viability percentage.

\subsection{Statistical analysis}

Statistical analyses were performed using ANOVA followed by Dunnett's test, performed using GraphPad Prism 5.0 (GraphPad Software, Inc). A $p$ value $<0.05$ was considered statistically significant.

\section{Results and Discussion}

The aqueous extract $A$. australe leaves gave the highest yield ( $28.5 \%$ based on dry weights) followed by the aqueous root extract (23\%), the hydroalcoholic leaf extract $(18.7 \%)$ and hydroalcoholic root extract $(8.8 \%)$. The chemical profiles of the leaf and root extracts differed with respect to the type of flavonoids and the presence or absence of saponins as shown in Table 1. These results confirm the findings of Adati (2006) and Castro (2012), even though the specimens of $A$. australe were collected at different locations and times of the year. According to Simões et al. (2004), the presence of tannins is associated with anti-diarrheal activity while condensed tannins and flavonoids are related to the antitumor properties of many plant species.

Table 1. Classes of secondary metabolites detected in leaf and root extracts of Acanthospermum australe.

\begin{tabular}{ccc}
\hline Class of compounds & Leaf extracts & Root extracts \\
\hline Alkaloids & $\circ$ & $\circ$ \\
Phenolics & $\bullet$ & $\bullet$ \\
Coumarins & $\circ$ & $\circ$ \\
Flavonoids & $\bullet$ Flavones & $\bullet$ Flavonones \\
Quinones & $\circ$ & $\circ$ \\
Saponins & $\bullet$ & $\circ$ \\
Tannins & $\bullet$ & $\bullet$ \\
\hline
\end{tabular}

$\circ$ Not detected; • Detected. 
The polyphenol contents of the extracts, as determined from the standard curve constructed using gallic acid $\left(\mathrm{y}=0.001 \times-0.00011 ; \mathrm{R}^{2}=0.99994\right)$, were: aqueous leaf extract - $129.26 \mathrm{mg} \mathrm{GAE} / \mathrm{g}$, aqueous root extract - 418.05 GAE/g, hydroalcoholic leaf extract - 129.87 GAE/g, and hydroalcoholic root extract - $399.78 \mathrm{GAE} / \mathrm{g}$. The roots of $A$. australe were the richest sources of polyphenols, whilst the amounts present in the leaf extracts were rather

The TTC technique employed to verify bacterial growth in the presence of $A$. australe extracts was found to be unreliable since not all of the assays in which bacterial growth could be observed by turbidity exhibited red coloration with the redox indicator. In contrast, the results obtained using the blue dye resazurin were consistent in revealing bacterial growth through formation of the pink fluorescent reduction product resorufin. Cells in wells that remained blue after incubation with resazurin showed a lack of respiratory activity and were subjected to further incubation on BHI medium to determine whether the extracts were bacteriostatic (MIC), bactericidal (MBC) or ineffective against the tested microorganisms that often cause infectious diarrhea.

As shown in Table 2, the aqueous leaf extract of $A$. australe showed bacteriostatic and bactericidal activities against E. faecalis, bacteriostatic activity against $S$. dysenteriae but was ineffective against $Y$. enterocolitica. The hydroalcoholic leaf extract showed similar activities against $E$. faecalis but was ineffective against $S$. dysenteriae and $Y$. enterocolitica. In contrast, the aqueous and hydroalcoholic root extracts were ineffective against $E$. faecalis and $Y$. enterocolitica but showed bacteriostatic activity against $S$. dysenteriae. In addition, the hydroalcoholic root extract showed bactericidal activity against $S$. dysenteriae.

In summary, none of the extracts of $A$. australe exhibited bacteriostatic or bactericidal activity towards $Y$. enterocolitica. The root extracts were ineffective against E. faecalis while the leaf extracts showed bactericidal activity towards this microorganism at $20 \mathrm{mg} / \mathrm{mL}$. The hydroalcoholic root extract was unique in exhibiting bactericidal activity against $S$. dysenteriae, although the effect was only observed at the highest concentration tested. These results demonstrate that the Gram-positive E. faecalis and the Gram-negative $S$. dysenteriae were susceptible to $A$. austral extracts, although such activities were only observed at concentrations that would be too high for clinical application.

Dietrich (2007) reported that the hydroalcoholic leaf extract from $A$. australe exhibited pronounced antifungal activities against Candida albicans, C. glabrata, C. dubliniensis and Cryptococcus neoformans at $0.5 \mathrm{mg} / \mathrm{mL}$, but low antibacterial activities against Bacillus subtilis, Staphylococcus aureus, Staphylococcus epidermidis, Escherichia coli, Klebsiella pneumoniae, Pseudomonas aeruginosa and Salmonella setubal. In contrast, the hydroalcoholic root extract exhibited low antifungal activity and an absence of antibacterial activity. In agreement with the results of the present study, Castro et al. (2012) found that aqueous and ethanolic extracts of $A$. australe exhibited bacteriostatic/bactericidal activities against $E$. coli and $S$. aureus at concentrations that were too high for clinical application. Moreover, Adati (2006) showed that the hydroalcoholic extract from the aerial parts of $A$. australe exhibited no significant activities against $S$. aureus, P. aeruginosa, E. coli and Candida albicans, although it presented a low activity towards Aspergillus niger at high concentrations.

It is important to emphasize that the distinction between bactericidal and bacteriostatic agents is only applicable to in vitro assays and is somewhat arbitrary for clinical situations and of limited relevance regarding the majority of infections. While, bacteriostatic/bactericidal data are valuable in determining potential action of antibacterial agents in vitro, according to Pankey and Sabath (2004) it is necessary to combine this information with pharmacokinetic and pharmacodynamic data in order to assess efficacy in vivo. Hence, the results reported herein only provide an indication of the properties of $A$. australe extracts and more investigations are needed fully to evaluate their potential

Table 2. Antimicrobial activities of leaf and root extracts from Acanthospermum australe as determined using the triphenyl tetrazolium chloride (TTC) and resazurin techniques.

\begin{tabular}{|c|c|c|c|c|c|c|c|c|c|c|c|c|}
\hline \multirow{3}{*}{ Extract $^{a}$} & \multicolumn{4}{|c|}{ Enterococcus faecalis } & \multicolumn{4}{|c|}{ Shigella dysenteriae } & \multicolumn{4}{|c|}{ Yersinia enterocolitica } \\
\hline & \multicolumn{2}{|c|}{ TTC } & \multicolumn{2}{|c|}{ Resazurin } & \multicolumn{2}{|c|}{ TTC } & \multicolumn{2}{|c|}{ Resazurin } & \multicolumn{2}{|c|}{ TTC } & \multicolumn{2}{|c|}{ Resazurin } \\
\hline & MIC $^{b}$ & MBC $^{c}$ & MIC $^{b}$ & MBC $^{\mathrm{c}}$ & MIC $^{b}$ & MBC $^{\mathrm{c}}$ & MIC $^{b}$ & MBC $^{\mathrm{c}}$ & MIC $^{b}$ & $\mathrm{MBC}^{\mathrm{c}}$ & MIC $^{b}$ & MBC $^{c}$ \\
\hline $\begin{array}{l}\text { Aqueous leaf } \\
\text { extract }(\mathrm{mg} / \mathrm{mL})\end{array}$ & $\mathrm{ND}^{\mathrm{d}}$ & $\mathrm{ND}^{\mathrm{d}}$ & 10 & 20 & 10 & $>20$ & 20 & $>20$ & 20 & $>20$ & $>20$ & $>20$ \\
\hline $\begin{array}{l}\text { Aqueous root } \\
\text { extract }(\mathrm{mg} / \mathrm{mL})\end{array}$ & $\mathrm{ND}^{\mathrm{d}}$ & $\mathrm{ND}^{\mathrm{d}}$ & $>20$ & $>20$ & 20 & $>20$ & 20 & $>20$ & 10 & $>20$ & $>20$ & $>20$ \\
\hline $\begin{array}{l}\text { Hydroalcoholic } \\
\text { leaf extract } \\
(\mathrm{mg} / \mathrm{mL})\end{array}$ & $\mathrm{ND}^{\mathrm{d}}$ & $\mathrm{ND}^{\mathrm{d}}$ & 10 & 20 & 5 & $>20$ & $>20$ & $>20$ & 20 & $>20$ & $>20$ & $>20$ \\
\hline $\begin{array}{l}\text { Hydroalcoholic } \\
\text { root extract } \\
(\mathrm{mg} / \mathrm{mL})\end{array}$ & $\mathrm{ND}^{\mathrm{d}}$ & $\mathrm{ND}^{\mathrm{d}}$ & $>20$ & $>20$ & 10 & 20 & 10 & 20 & 5 & $>20$ & $>20$ & $>20$ \\
\hline
\end{tabular}

${ }^{\mathrm{a}}$ Concentration range $5-20 \mathrm{mg} / \mathrm{mL} .{ }^{b}$ Minimum inhibitory concentration; bacteriostatic at the concentration specified. ${ }^{\mathrm{c}}$ Minimum bactericidal concentration; bactericidal at the concentration specified. ${ }^{\mathrm{d}}$ Could not be determined using the TTC technique. 
against pathogenic or potentially pathogenic enterobacteria. Our findings are important, however, since $S$. dysenteriae, which causes diarrhea, fever and abdominal pain, often with serious complications, has been classified as an urgent threat in the United States (Centers for Disease Control and Prevention, 2013) because of acquired resistance to first-line and other important antibiotics (Takeda et al., 2011; Zhang et al. 2014). Moreover, E. faecalis is one of the leading causes of nosocomial infections, most of which occur after puncturing trauma or surgery of the abdomen. The bacterium is also responsible for urinary tract infections, bacteremia, endocarditis, meningitis and wound infections (Kau et al., 2005).

Toxicity tests can be performed in vitro using a diverse variety of mammalian cells, including normal adult tissues, embryo and tumor cells, although the last mentioned are more easily cultured because they exhibit higher growth capability and adapt readily to external variations. In this context, Chinese hamster ovary cells $\mathrm{CHO}-\mathrm{K} 1$ have been employed in numerous genetic, toxicity screening, nutrition and gene expression studies. Determination of the viability of such cells in the presence of the test substance provides an indication of toxicity and can be performed readily using vital dyes such a trypan blue that can only enter dead cells.

A plant extract is generally considered toxic when its $\mathrm{IC}_{50}$ is lower than $30 \mu \mathrm{g} / \mathrm{mL}$ (Itharat et al., 2004). In the present case, more than $80 \%$ of the $\mathrm{CHO}-\mathrm{K} 1$ cells remained viable when extracts of $A$. australe were applied at a concentration of $100 \mu \mathrm{g} / \mathrm{mL}$, indicating that the leaf and root extracts exhibited no significant toxicity. The greater reduction on the cell viability was observed by the EAF extract which showed a reduction of $12.45 \pm 3.78 \%$ on the cell viability (Figure 1). In contrast, Dietrich (2007) observed that $\mathrm{T} 24$ human bladder carcinoma cells were more susceptible to hydroalcoholic leaf extracts of $A$. australe in

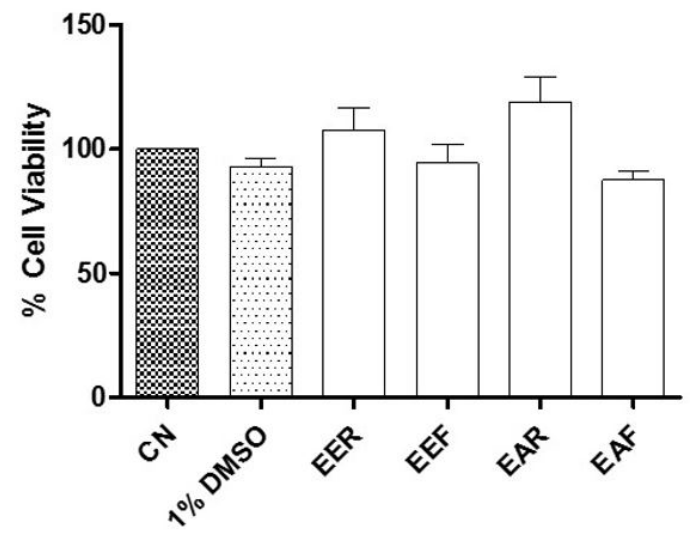

[ ] $100 \mu \mathrm{g} / \mathrm{mL}$

Figure 1. Cell viability after 48 hours of exposure to $100 \mu \mathrm{g} / \mathrm{mL}$ of the EER, EEF, EAR and EAF extracts evaluated by the Alamar Blue method. The results are presented using percentage of the control $(n=3)$. $P<0.05$; ANOVA followed by the Dunnett test when compared to the control $(\mathrm{CN})$. comparison with hydroalcoholic root extracts. Given that dissimilar cell lines often present differential responses, it is important to carry out assays with various cell types better to predict toxicity in humans.

The present study demonstrated that the aqueous and hydroalcoholic extracts from leaves and roots of $A$. australe are effective against E. faecalis and $S$. dysenteriae, although in vitro bacteriostatic/bactericidal activities were observed only when the extracts were applied at elevated concentrations $(10-20 \mathrm{mg} / \mathrm{mL})$ that would not be appropriate in clinical practice or in the production of phytopharmaceuticals.

It is important to emphasize the importance of cytotoxicity studies with plants that are used by the general population, and in the concentrations, that approximate those used in teas. In the results of the present study, there were no toxic concentrations, but as already demonstrated by Cardoso et al. (2014) some plants that are commonly used by the population have a cytotoxic potential, even in the lower concentrations, and further studies are necessary to obtain greater safety in the use of medicinal plants.

The activities of the extracts tested in this study are likely associated with the presence of flavonoids and tannins, but further studies are required in order to determine the exact nature of the active components and their anti-diarrhea effects in vivo. The results presented herein support the ethnopharmacological use of $A$. australe in the treatment of gastrointestinal disorders, particularly diarrhea caused by infectious enterobacteria.

\section{Acknowledgements}

The authors wish to thank to Fundação de Amparo à Pesquisa do Estado do Rio Grande do Sul (FAPERGS) and Conselho Nacional de Desenvolvimento Científico e Tecnológico (CNPq; PRONEX-10/0029-0) for part of financial support.

\section{References}

ADATI, R.T. 2006. Estudo biofarmacognóstico de Acanthospermum australe (Loefl) O. Kuntze-Asteraceae. São Paulo: Universidade de São Paulo, 142 p. Tese de Doutorado em Fármaco e Medicamentos, Área de Insumos Farmacêuticos.

CARDOSO, G.H.S., DANTAS, E.B.S., SOUSA, F.R.C. and PERON, A.P., 2014. Cytotoxicity of aqueous extracts of Rosmarinus officinalis L. (Labiatae) in plant test system. Brazilian Journal of Biology $=$ Revista Brasileira de Biologia, vol. 74, no. 4, pp. 886889. PMid:25627599. http://dx.doi.org/10.1590/1519-6984.07313.

CASTRO, L.C. 2012. Avaliação das atividades antibacteriana e amebicida dos extratos aquoso e etanólico de Acanthospermum australe (Loefl.) O. Kuntze. Porto Alegre: Universidade Federal do Rio Grande do Sul, 71 p. Tese de Doutorado em Microbiologia Agrícola e do Ambiente.

CASTRO, L.C., DALL'AGNOL, R., ETHUR, E.M., WEIDLICH, L., KAUFFMANN, C., SAUTER, I.P., MUNIZ, A.W., LOHMANN, P.M., BOUCHARCOURT, O., GERMANI, J.C. and VAN DER SAND, S.T., 2012. Avaliação da atividade 
antimicrobiana de extrato aquoso e etanólico de Acanthospermum australe. Caderno Pedagógico, vol. 9, no. 2, pp. 153-161.

CENTERS FOR DISEASE CONTROL AND PREVENTION - CDC, 2013 [viewed 5 September 2015]. Antibiotic resistance threats in the United States. Available from: http://www.cdc. gov/drugresistance/threat-report-2013/pdf/ar-threats-2013-508. pdf\#page $=75$

CHAKRABORTY, A.K., GAIKWAD, A.V. and SINGH, K.B., 2012. Phytopharmacological review on Acanthospermum hispidum. Journal of Applied Pharmaceutical Science, vol. 2, no. 1, pp. 144-148.

CLINICAL AND LABORATORY STANDARDS INSTITUTE - CLCI, 2012. Methods for dilution antimicrobial susceptibility test for bacteria that grow aerobically. Pennsylvania: NCCLS. NCCLS Document M07-A9.

DIETRICH, F. 2007. Avaliação de atividades biológicas do extrato hidroetanólico de folhas e raizes de Acanthospermum australe (Loefl.) O. Kuntze. Lajeado: Centro Universitário UNIVATES, 72 p. Monografia de Graduação em Farmácia.

FRESHNEY, R.I. 2010. Culture of animal cells: a manual of basic technique and specialized applications. 6th ed. John Hoboken: Wiley \& Sons Inc. $732 \mathrm{p}$.

FLORA DIGITAL DO RIO GRANDE DO SUL. 2015 [viewed 5 September 2015]. Available from: http://www.ufrgs.br/fitoecologia/ florars/open_sp.php?img $=8263$

HARBONE, J.B. 1998. Phytochemial methods: a guide to modern techniques of plant analysis. 3rd ed. Netherlands: Springer. 302 p.

HÖFLING, J.F., ANIBAL, P.C., OBANDO-PEREDA, G.A., PEIXOTO, I.A., FURLETTI, V.F., FOGLIO, M.A. and GONÇALVES, R.B., 2010. Antimicrobial potential of some plant extracts against Candida species. Brazilian Journal of Biology $=$ Revista Brasileira de Biologia, vol. 70, no. 4, pp. 1065-1068. PMid:21180915. http://dx.doi.org/10.1590/S151969842010000500022

ITHARAT, A., HOUGHTON, P.J., ENO-AMOOQUAYE, E., BURKE, P.J., SAMPSON, J.H. and RAMAN, A., 2004. In vitro cytotoxic activity of thai medicinal plants used traditionally to treat cancer. Journal of Ethnopharmacology, vol. 90, no. 1, pp. 33-38. PMid:14698505. http://dx.doi.org/10.1016/j.jep.2003.09.014.

KAU, A.L., MARTIN, S.M., LYON, W., HAYES, E., CAPARON, M.G. and HULTGREN, S.J., 2005. Enterococcus faecalis tropism for the kidneys in the urinary tract of $\mathrm{C} 57 \mathrm{BL} / 6 \mathrm{~J}$ mice. Infection and Immunity, vol. 73, no. 4, pp. 2461-2468. PMid:15784592. http://dx.doi.org/10.1128/IAI.73.4.2461-2468.2005.
LORENZI, H. and MATOS, F.J.A. 2002. Plantas medicinais no Brasil: nativas e exóticas. 2nd ed. São Paulo: Instituto Plantarum de Estudos da flora Ltda. 576 p.

PANKEY, G.A. and SABATH, L.D., 2004. Clinical relevance of bacteriostatic versus bactericidal mechanisms of action in the treatment of gram-positive bacterial infections. Clinical Infectious Diseases, vol. 38, no. 6, pp. 864-870. PMid:14999632. http:// dx.doi.org/10.1086/381972.

RODRIGUES, V.E.G. and CARVALHO, D.A., 2001. Levantamento etnobotânico de plantas medicinais do domínio do cerrado na região do Alto Rio Grande - Minas Gerais. Ciência e Agrotecnologia, vol. 25 , no. 1 , pp. $102-123$

SILVA JUNIOR, I.F., OLIVEIRA, R.G., SOARES, I.M., ALVIM, T.C., ASCÊNCIO, S.D. and MARTINS, D.T.O., 2014. Evaluation of acute toxicity, antibacterial activity, and mode of action of the hydroethanolic extract of Piper umbellatum $L$. Journal of Ethnopharmacology, vol. 151, no. 1, pp. 137-143. PMid:24189034. http://dx.doi.org/10.1016/j.jep.2013.10.011.

SIMÕES, C.M.O., SCHENCKEL, E.P., GOSMANN, G., MELLO, J.C.P., MENTZ, L.A. and PETROVICK, P.R., orgs., 2004. Farmacognosia: da planta ao medicamento. 5th ed. Porto Alegre: Editora da UFRGS, Florianópolis: Editora da UFSC.

SOUSA, C.M., SILVA, H.R., VIEIRA-JUNIOR, G.M., AYRES, M.C.C., COSTA, C.L.S., ARAÚJO, D.S., CAVALCANTE, L.C.D., BARROS, E.D.S., ARAÚJO, P.B.M., BRANDÃO, M.S. and CHAVES, M.H., 2007. Fenóis totais e atividade antioxidante de cinco plantas medicinais. Quimica Nova, vol. 30, no. 2, pp. 351-355. http://dx.doi.org/10.1590/S0100-40422007000200021.

TAKEDA, Y., NIYOGI, S.K., RAJENDRAN, K., GUIN, S., BHATTACHARYA, M.K., PAZHANI, G.P., RAMAMURTHY, T., GHOSH, S., NAIR, G.B., DUTTA, S. and CHOWDHURY, G., 2011. Genetic characteristics and changing antimicrobial resistance among Shigella spp. isolated from hospitalized diarrhoeal patients in Kolkata, India. Journal of Medical Microbiology, vol. 60, no. Pt 10, pp. 1460-1466. PMid:21659504. http://dx.doi. org/10.1099/jmm.0.032920-0.

VEIGA JÚNIOR, V.F., PINTO, A.C. and MACIEL, M.A., 2005. Plantas medicinais: cura segura? Quimica Nova, vol. 28, no. 3, pp. 519-528. http://dx.doi.org/10.1590/S0100-40422005000300026.

WORLD HEALTH ORGANIZATION - WHO, 2013 [viewed 5 September 2015]. Diarrhoeal disease: fact sheet no. 330. Available from: http://www.who.int/mediacentre/factsheets/fs330/en/

ZHANG, J., JIN, H., HU, J., YUAN, Z., SHI, W., YANG, X., XU, X. and MENG, J., 2014. Antimicrobial resistance of Shigella spp. from humans in Shanghai, China, 2004-2011. Diagnostic Microbiology and Infectious Disease, vol. 78, no. 3, pp. 282-286. PMid:24387959. http://dx.doi.org/10.1016/j. diagmicrobio.2013.11.023. 